Georgetown University Law Center

Scholarship @ GEORGETOWN LAW

1995

\title{
Fighting Domestic Violence in the Nation's Capital
}

Deborah Epstein

Georgetown University Law Center, epstein@law.georgetown.edu

This paper can be downloaded free of charge from:

https://scholarship.law.georgetown.edu/facpub/1710

http://ssrn.com/abstract=2805174

3 Geo. J. on Fighting Poverty 93

This open-access article is brought to you by the Georgetown Law Library. Posted with permission of the author. Follow this and additional works at: https://scholarship.law.georgetown.edu/facpub

Part of the Family Law Commons, and the Law and Gender Commons 


\section{Fighting Domestic Violence in the Nation's CAPITAL}

\section{Deborah Epstein}

\section{Domestic Violence: The Scope of THE PROBLEM}

"[Battered women]" are run over by cars and trucks. They have their teeth knocked out with hammers. They are raped with hot curling irons and large objects. They are stabbed with screwdrivers, ice picks and knives. They are beaten, choked and strangled. They are beaten in public in the streets. They are beaten in the privacy of their own homes, often in front of their children. And they are tied up and forced to watch the torture and sexual molestation of their own children.... [These are] the atrocities that constitute domestic violence as it occurs across the country and, indeed, around the world. ${ }^{1}$

Every year, in the District of Columbia alone, the Metropolitan Police Department receives more than 18,000 calls for help from victims of domestic violence, and more than 2,500 battered women bring legal actions requesting protection from their abusers. Thousands of other cases go unreported, either because the victims are too afraid of their batterers to report the violence, or because they do not know how to obtain relief to which they are entitled.

Battered women who are economically dependent on their abusers face particularly serious obstacles. Most welfare offices require thirty days to make an eligibility determination, leaving victims with no financial assistance during the critical period immediately after they leave. Battered women with children are especially vulnerable; most shelters around the country are restricted to adult occupancy and, without a court award of child support, the financial burden on these women is overwhelming. Legal resources available to victims of domestic violence are scarce. In the District of Columbia, fewer than $20 \%$ of the low-income victims who file suit for a civil protection order are represented by counsel.

\section{STUDENT REPRESENTATION OF DOMESTIC VIOLENCE VICTIMS}

Under the supervision of Clinic professors, Georgetown students represent indigent victims of domestic violence seeking protection from abuse. Clinic students undergo intensive instruction in the civil and criminal law applicable to domestic violence litigation, as well as the law of evidence, civil procedure, and legal ethics. Through simulation exercises, students develop and refine essential litigation skills, such as drafting complaints and motions, conducting direct and cross examination, and delivering opening statements and closing arguments. Students then put their knowledge and skills to work by representing at least three clients from initial interview to settlement or trial in civil protection order (CPO) actions in D.C. Superior Court.

Pursuant to the local Intrafamily Offenses Act, a CPO lasts for up to one year and can include a broad spectrum of relief designed to effectively end the violence in a family or dating relationship. A CPO may direct the batterer to cease assaulting and threatening his target; to stay away from her home, person, and workplace; and not to contact her in any manner. It may award temporary custody of the parties' minor children, with visitation rights for the non-custodial parent (a particularly important provision in cases where the battereer uses the children to harass their mother), and award child and/or spousal support, so that a victim is not forced back to her batterer due to economic necessity.

If an abuser refuses to comply with a CPO, students file a motion seeking to 
have him held in contempt of court. Local law provides that a willful violation of a CPO is punishable by six months imprisonment, a $\$ 300$ fine, or both. After graduating from Georgetown, Clinic students often continue to work against domestic abuse by doing pro bono work in their communities.

\section{The Emergency Domestic Relations Project: A Special Clinic UNDERTAKING}

In addition to providing legal representation to victims of family abuse, Clinic Professors Susan Deller Ross and Deborah Epstein serve as co-directors of the Emergency Domestic Relations Project (EDRP or the Project), a special Clinic program designed to provide highvolume services to the thousands of indigent victims of domestic violence who need civil protection orders. EDRP is staffed primarily by Project Manager Meshall Thomas, who has spent the past eighteen years working on family abuse issues in the District of Columbia.

The Project tries to maximize the number of attorneys available to assist domestic violence petitioners. Through the efforts of Ms. Thomas and Professors Ross and Epstein, the Project has trained hundreds of volunteer attorneys who in turn agree to take cases on a pro bono basis. The Project provides each volunteer attorney with a mentor, a lawyer experienced in handling domestic violence cases, who will help handle any problems or difficult issues that may arise. The Project then refers victims who are unable to afford legal counsel and face particularly difficult legal battles to the trained volunteer attorneys. Petitioners who obtain representation through the Project's attorney referral program are far more likely to obtain complete and effective relief. As one example, Meshall Thomas recently met with a young mother whose boyfriend had burned her arm with a hot iron, leaving a visible imprint. Ms. Thomas successfully referred her to a pro bono EDRP-trained lawyer who took her case and helped her obtain a CPO that directed the boyfriend not to assault or threaten the woman, ordered him to undergo domestic violence counseling, and awarded her custody of the parties' three young children.

Due to the sheer volume of domestic violence cases in the District of Columbia, the Project cannot ensure that all victims obtain free legal representation. Accordingly, Meshall Thomas and her interns contact, in advance, every petitioner whose case is scheduled for a hearing on the D.C. Superior Court domestic violence calendar. EDRP staff members describe to each petitioner how to navigate the judicial process, what she should expect to happen on the hearing date, and the full scope of relief available to her. The Project also provides each victim with valuable information about how to best prove her case in court, emphasizing the importance of witnesses and physical evidence, such as photographs, hospital records, and police reports.

Finally, Project staff members are on duty every morning in D.C. Superior Court, meeting with the parties in every pro se domestic violence case immediately before the scheduled hearing. In these meetings, EDRP staff assist petitioners by negotiating on their behalf with the batterers in an attempt to reach a consent order. By obtaining consent CPOs, EDRP allows petitioners to obtain the relief they desire without having to go through the ordeal of a formal courtroom hearing and streamlines the court docket, freeing judges to hear greater numbers of domestic violence cases that require contested hearings without unnecessary delay. Last year, the Project successfully negotiated over 1,000 consent CPOs. Victims of abuse often hug and kiss EDRP staff members after receiving their help, telling them that they 
could not have made it through the legal process alone.

\section{Client Stories}

The stories of a few of the many women whom the Sex Discrimination Clinic has helped, either through legal representation by Clinic students or through the work of the Emergency Domestic Relations Project, illustrate the scope and significance of the Clinic's work.

\section{A. Leslie}

Leslie and her husband were married for eight years and had a five-year-old son. Her husband physically and emotionally abused her throughout the marriage, including several incidents when he threw her to the ground and hit her while she was pregnant with their child. On another occasion, he punched her in the face and kicked her while she held their two week-old infant son in her arms. In February 1995, he became angry with Leslie and began to yell at her and shove her in front of their child. The boy became upset and placed himself between his parents, yelling "Don't hurt my mother!" His father responded by slamming the little boy's head and back into a wall. Leslie told her husband she wanted a divorce, and he moved out of the family home. But several weeks later, Leslie's husband followed her out of a teacher's meeting at their son's preschool, grabbed her by the arm, and told her, "If I'm not going to have you, no one can." In the weeks that followed, he repeatedly came to Leslie's home and assaulted or threatened her. Terrified of what her husband would do next, Leslie was forced to leave with her son and stay with relatives.

Sex Discrimination Clinic students represented Leslie, and after two hotly contested hearings on issues of domestic violence and child support, the court granted her a civil protection order requiring her husband to stay away from her and their home, not to assault or threaten her, and ordering him to participate in domestic violence counseling. The order also awarded temporary custody of the couple's son to Leslie, granted her husband limited visitation rights, and ordered him to pay more than $\$ 700$ a month in child support.

\section{B. Jane}

Jane had been married for twelve years and had four children. On numerous occasions throughout their marriage, Jane's husband, a drug abuser, has assaulted her and threatened to harm her. Most recently, in early June 1995, Jane's husband shoved her and threatened to kill her. He then left home and returned with a gun. He held his wife at gun point and again threatened to kill her, then punched and choked her until she lay on the floor of their home unconscious.

Two hours later, Jane regained consciousness and called the police. But when the police arrived, they refused to arrest her husband or help her to move her four young children out of the home she shared with her batterer. Fearing for her life, Jane was forced to leave her own home without her children to seek a safe refuge.

Jane arrived at the Emergency Domestic Relations Project a few days later. She was extremely distraught; her neighbors had told her that her husband had left the children alone with no food, and her two youngest children had been seen playing outside, unsupervised, at three a.m. A Project staff member interviewed Jane, helped her draft a petition for a $\mathrm{CPO}$, and prepared her to speak with a judge on an emergency basis to get a temporary protection order. By the time she left the courthouse that day, Jane had a temporary order in hand directing her husband to leave the family home so that she could safely move back in, awarding her temporary custody of her four children, ordering her husband not to assault or threaten her, and ordering him to stay away from her and the children. The Project also arranged for 
an attorney to represent Jane two weeks later at a hearing where she obtained a permanent CPO.

\section{Danielle}

Soon after Danielle began dating her new boyfriend, things started to go wrong. One day he assaulted her by choking her and pulling her hair out, inflicting serious injuries. He had made a duplicate key to her apartment without her permission, and when she went to the hospital for treatment he ransacked her apartment. He destroyed her furniture, dishes, television and stereo, and stole $\$ 40$ worth of food stamps.

When Danielle came to the courthouse to lodge a complaint, a Project staff member helped her to prepare a petition for a CPO and a motion for a temporary protection order to restrain her new boyfriend from contacting her or destroying any more of her property. Danielle successfully obtained the tempo- rary order, and when she returned for her full hearing two weeks later, a Project staff member negotiated with her boyfriend on her behalf. The Project convinced him to consent to the entry of a CPO without a hearing, and the order, signed into law by the presiding judge, directed Danielle's boyfriend to stop his abuse, stay away from her, and pay close to a thousand dollars in restitution for the property that he had destroyed.

As these stories show, the Clinic has made an enormous contribution to the fight against domestic violence. As one former client put it, "Since you helped me get my CPO, [my batterer] has left me alone and I've been safe for the first time in years. Working with you has changed my life."

\section{Notes}

${ }^{1}$ Sarah Buel, The Dynamics of Domestic Violence Cases in the United States: An Overview, in DEFENDing Battered Women IN CRiminal CASES $\$$ A at 1 (1993). 